DOI

\title{
ВИКОРИСТАННЯ МІЖПРЕДМЕТНОЇ ІНТЕГРАЦІЇ ПРИ ПІДГОТОВЦІ СТУДЕНТІВ ФАРМАЦЕВТИЧНОГО ФАКУЛЬТЕТУ ДО ДЕРЖАВНОЇ АТЕСТАЦІї
}

\author{
О. В. Кривов'яз, Ю. О. Томашевська, М. С. Гарник \\ Вінницький національний медичний університет імені М. I. Пирогова

\section{INTERDISCIPLINARY INTEGRATION APPLYING AT PHARMACEUTICAL STUDENTS' TRAINING FOR STATE VALIDATION} \\ O. V. Kryvoviaz, Yu. O. Tomashevska, M. S. Harnyk \\ Vinnytsia National Medical University by M. I. Pyrohov
}

\begin{abstract}
Розглянуто і теоретично узагальнено актуальні питання підготовки випускників фармацевтичного факультету до державної атестації. Викладено результати впровадження інноваційної форми міждисциплінарного тестового контролю, яка передбачає використання завдань із різних предметів, що охоплюють спільну тему. Особливу увагу приділено необхідності інтегрованого вивчення таких дисциплін, як: аптечна технологія лікарських засобів, фармакогнозія, фармакологія, промислова технологія лікарських засобів, фармацевтична хімія.
\end{abstract}

Live issues of pharmaceutical university-leaving students' training for state validation have been reviewed and theoretically generalized. Interdisciplinary test control innovation form applying results have been represented. Interdisciplinary test control implies application of different questions combined by a common topic. Particular attention has been paid to an integrated study of such subjects as drug technology, pharmacognosy, pharmacology, industrial drug technology and pharmaceutical chemistry.

Вступ. Фармацевтична галузь на сучасному етапі особливо потребує високоосвічених креативних фахівців, які здатні вільно аналізувати та використовувати в професійній діяльності постійно зростаючі обсяги інформації. Тому викладання професійноорієнтованого комплексу дисциплін повинно бути спрямоване на формування цілісного комплексного сприйняття навчального матеріалу. Важливу роль при цьому відіграє реалізація міждисциплінарних зв’ язків - вирішення однієї проблеми з урахуванням всіх отриманих знань [2, 3, 5, 7].

Для систематичного контролю ступеня сформованості професійних умінь та навичок студентів використовується поточний, підсумковий контроль та державна атестація, що проводяться відповідно до нормативних вимог Міністерства охорони здоров’я України та Міністерства освіти і науки України.

Стандартизований тестовий державний іспит “Крок 2” - це ліцензійний інтегрований іспит, який є складовою частиною державної атестації випускників вищих навчальних закладів i вимірює показники якості фахової компетентності спеціаліста фармації.

(ㄱ О. В. Кривов’яз, Ю. О. Томашевська, М. С. Гарник
Великі труднощі у студентів виникають при вивченні теми “Алкалоїди”. Алкалоїди - велика група вторинних азотовмісних речовин, переважно рослинного походження, більшість з яких має виражену фармакологічну дію на організм людини та тварин [6, 9]. На сьогодні у практичній медицині використовують близько 100 алкалоїдів, які застосовують як у чистому вигляді, так і у вигляді водних та спиртових витягів, екстрактів з лікарської рослинної сировини $[1,4,8]$. Незважаючи на широкий спектр фармакологічної дії даної групи біологічно активних сполук, спеціаліст фармації повинен пам'ятати, що алкалоїди мають також і низку суттєвих негативних властивостей: при застосуванні деяких алкалоїдів виникає залежність, багато з них є сильнодіючими та отруйними речовинами, які здатні призвести до летального наслідку. Тому заготівлю, сушіння і зберігання алкалоїдвмісної сировини, виготовлення та застосування препаратів алкалоїдів проводять 3 урахуванням їх токсичності $[1,4,6,8,9]$. Необхідні знання з даної теми студенти здобувають під час вивчення фармакогнозії, технології лікарських засобів, фармакології, фармацевтичної хімії.

Метою нашої роботи є розробка інноваційної форми міждисциплінарного тестового контролю, 
яка передбачає використання завдань із різних дисциплін, що охоплюють спільну тему.

Основна частина. Протягом 2011-2015 рр. було здійснено тестування трьох потоків вітчизняних студентів денної форми навчання спеціальності 7.12020101 “Фармація” фармацевтичного факультету Вінницького національного медичного університету імені М. І. Пирогова. Для проведення тестування студенти, починаючи з третього року навчання, залучались тричі:

1 - на третьому курсі під час вивчення теми “Алкалоїди” з кожної окремої дисципліни (аптечна технологія лікарських засобів, фармакогнозія, фармакологія);

2 - на четвертому курсі - окремо з промислової технології лікарських засобів та фармацевтичної хімії, вивчаючи відповідні теми;
3 - на п’ятому курсі - мультидисциплінарне тестування в рамках підготовки до державної атестації.

Результат тестування оцінювали у відсотках.

На основі аналізу галузевих стандартів вищої освіти “Освітньо-кваліфікаційна характеристика спеціаліста за спеціальністю 7.110201 Фармація напряму підготовки 1102 Фармація” та “Освітньопрофесійна програма підготовки спеціаліста за спеціальністю 7.110201 Фармація напряму підготовки 1102 Фармація кваліфікації 2442.6 Провізор” було розроблено план засвоєння теми “Алкалоїди” в аспекті фармакогнозії, технології лікарських засобів, фармакології та фармацевтичної хімії (табл. 1) $[1,4,6,8,9]$.

Таблиця 1. План засвоєння теми “Алкалоїди” студентами III-IV курсів фармацевтичного факультету спеціальності 7.12020101 - Фармація

\begin{tabular}{|c|c|c|}
\hline $\begin{array}{c}\text { Назва навчальної } \\
\text { дисципліни }\end{array}$ & Розділ, у межах якого вивчається тема “Алкалоїди” & Предмет вивчення \\
\hline $\begin{array}{l}\text { Аптечна технологія } \\
\text { лікарських засобів }\end{array}$ & $\begin{array}{l}\text { Порошки з екстрактами } \\
\text { Розчини ВМС } \\
\text { Водні витяги з лікарської рослинної сировини та } \\
\text { екстрактів-концентратів } \\
\text { Супозиторії } \\
\text { Несумісності }\end{array}$ & $\begin{array}{l}\text { Фармацевтична експертиза } \\
\text { рецепта, особливості технології } \\
\text { екстемпоральних ЛФ, до складу } \\
\text { яких входять ЛР-алкалоїди }\end{array}$ \\
\hline Фармакогнозія & $\begin{array}{l}\text { Алкалоїди. Загальна характеристика групи БАР. } \\
\text { Методи якісного та кількісного визначення. Лікарські } \\
\text { рослини і сировина, які містять алкалоїди }\end{array}$ & $\begin{array}{l}\text { Загальна характеристика, осо- } \\
\text { бливості збору, сушіння, збе- } \\
\text { рігання, реакції ідентифікації, } \\
\text { макро- та мікроскопічні ознаки } \\
\text { ЛРС }\end{array}$ \\
\hline Фармакологія & $\begin{array}{l}\text { Місцевоанестезуючі засоби } \\
\text { Засоби, які впливають на холінергічні та адренергічні } \\
\text { синапси } \\
\text { Аналгезивні засоби } \\
\text { Психомоторні стимулятори } \\
\text { Речовини, що впливають на функції органів дихання } \\
\text { Речовини, що впливають на серцево-судинну систему } \\
\text { Фітотерапевтичні засоби }\end{array}$ & $\begin{array}{l}\text { Фармакологічні властивості } \\
\text { та особливості застосування } \\
\text { препаратів, що містять алкало- } \\
\text { їди }\end{array}$ \\
\hline $\begin{array}{l}\text { Промислова тех- } \\
\text { нологія лікарських } \\
\text { засобів }\end{array}$ & Екстракційні препарати & $\begin{array}{l}\text { Особливості технології готових } \\
\text { ЛФ, до складу яких входять } \\
\text { ЛР-алкалоїди }\end{array}$ \\
\hline $\begin{array}{l}\text { Фармацевтична } \\
\text { хімія }\end{array}$ & $\begin{array}{l}\text { Лікарські засоби, похідні індолу, імідазолу, } \\
\text { піридин-3-карбонової кислоти, тропану, ізохіноліну, } \\
\text { морфінану і морфану, пурину }\end{array}$ & $\begin{array}{l}\text { Методи кількісного та якісного } \\
\text { аналізу алкалоїдів }\end{array}$ \\
\hline
\end{tabular}

На основі даного плану була розроблена база тестових завдань першого рівня складності (кожне завдання містило по 5 дистракторів, з яких студент повинен обрати один правильний) за темою “Алкалоїди” з кожної зазначеної навчальної дис- ципліни. В подальшому цю базу було використано для формування 20 варіантів інтегрованих мультидисциплінарних завдань по 100 тестових завдань (20 з кожного предмета) та комплекти завдань 3 окремих дисциплін. 
Після обробки бланків відповідей було встановлено, що результат проведеного тестування на окремих дисциплінах під час вивчення теми “Алкалої- ди” був значно нижчим у порівнянні з показниками мультидисциплінарного тестування (табл. 2).

Таблиця 2. Результати тестування студентів за темою “Алкалоїди”

\begin{tabular}{|c|c|c|c|}
\hline \multirow{2}{*}{$\begin{array}{c}\text { Роки навчання } \\
\text { на III-V курсах }\end{array}$} & \multicolumn{3}{|c|}{ Результати тестування, \% } \\
\cline { 2 - 4 } & III курс & IV курс & $\begin{array}{c}\text { мультидисциплінарне } \\
\text { тестування (V курс) }\end{array}$ \\
\hline $\begin{array}{c}2011-13 \\
(\mathrm{n}=38)\end{array}$ & 65,8 & 77,6 & 85,3 \\
\hline $\begin{array}{c}2012-14 \\
(\mathrm{n}=30)\end{array}$ & 63,2 & 76,2 & 85,2 \\
\hline $\begin{array}{c}2013-15 \\
(\mathrm{n}=32)\end{array}$ & 68,4 & 78,1 & \\
\hline
\end{tabular}

Примітка. n - кількість студентів, що брали участь у тестуванні.

Такі результати пояснюються тим, що протягом навчання у студентів постійно зростає усвідомлення міждисциплінарних зв'язків, мотивація до навчання $є$ значно вищою, постійно накопичується інформація з різних дисциплін у межах кожного розділу, яка логічно доповнює попередньо вивчений матеріал теми на інших дисциплінах.

\section{Список літератури}

1. Фармацевтична хімія / [О. П. Безуглий, І. В. Українець, С. Г. Таран та ін.]. - Вінниця : НОВА КНИГА, 2008. - 568 c.

2. Бобрук В. П. Педагогічні аспекти викладання фармакології та організації економіки фармації із залученням інтегрованого підходу / В. П. Бобрук, С. В. Сергєєв, О. Д. Благун // Вісник ВНМУ ім. М. І. Пирогова, 2012. Т. 16, № 2. - С. 460-463.

3. Давыдов В. В. Виды обобщения в обучении: логикопсихологические проблемы построения учебных предметов / В. В. Давыдов. - М. : Пед. о-во России, 2010. -480 c.

4. Технологія лікарських препаратів промислового виробництва / [Д. І. Дмитрієвський, Л. І. Богуславська, Л. М. Хохлова та ін.]. - Вінниця : НОВА КНИГА, 2008. -277 c.
Висновок. Впровадження мультидисциплінарного інтегрованого тестування з кожної теми завдяки систематизації матеріалу та цілісного усвідомлення питання студентами дає змогу подолати розрізненість знань та досягти високого рівня засвоєння як кожної окремої теми, так і циклу професійноорієнтованих дисциплін у цілому.

5. Окса М. М. Інновації як передумова зростання педагогічної майстерності менеджера освітнього закладу / М. М. Окса // Сучасні суспільні проблеми у вимірі соціології управління: збірник наукових праць ДонДУУ. - 2009. - Т. Х. - Вип.115. - 347 с.

6. Практикум з ідентифікації лікарської рослинної сировини : навч. посіб. / за ред. В. М. Ковальова, С. М. Марчишин. - Тернопіль : ТДМУ, 2014. - 264 с.

7. Сергєєв С. В. Сучасні педагогічні прийоми та інноваційні технології в навчальному процесі у вищому навчальному закладі / С. В. Сергєєв // Вісник ВНМУ ім. М. І. Пирогова, 2013. - Т. 19, № 1. - 4 с.

8. Тихонов О. І. Аптечна технологія ліків / О. І. Тихонов, Т. Г. Ярних ; під ред. О. І. Тихонова. - Вінниця : НОВА КНИГА, 2004. - 640 с.

9. Фармакологія : підруч. для студ. вищ. мед. навч. закл. / [І. С. Чекман та ін.]. - Вінниця : НОВА КНИГА, 2009. -480 c. 